\title{
Cyber Bullying Against Children in Indonesia
}

\author{
Laurensius Arliman S ${ }^{1}$, Danel Aditia Situngkir ${ }^{2}$, Hariyadi ${ }^{3}$, Rianda Rindra Putri ${ }^{4}$, Rahmat \\ Fauzi ${ }^{5}$, Gokma Toni Parlindungan $\mathrm{S}^{6}$ \\ \{laurensiusarliman@gmail.com ${ }^{1}$, danel@stba-prayoga.ac.id², hariyadi@umsb.ac.id ${ }^{3}$, \\ rindra2201rianda@gmail.com ${ }^{4}$,rahmatfauzi24oke@gmail.com ${ }^{4}$,gokmatoniparlindungan@ gmail.com $\left.{ }^{5}\right\}$ \\ Faculty of Law, Universitas Andalas, Padang, Indonesia ${ }^{1}$, Sekolah Tinggi Bahasa Asing Prayoga, \\ Padang, Indonesia ${ }^{2}$, Universitas Muhammadiyah Sumatera Barat, Padang, Indonesia ${ }^{3}$ Sekolah Tinggi \\ Ilmu Sosial dan Ilmu Politik Imam Bonjol, Indonesia ${ }^{4}$, Sekolah Tinggi Ilmu Hukum Putri Maharaja, \\ Indonesia ${ }^{5}$, Sekolah Tinggi Ilmu Hukum Padang, Indonesia ${ }^{6}$ )
}

\begin{abstract}
Bullying is the user of violence, threats, or coercion to abuse or intimidates others. Threats and insults at this time are carried out not only directly through face to face between the perpetrator and the victim but can be done through intermediary means, such as cell phones, short messages, or social media. Not infrequently bullying on social media places children as victims. The approach method used in this study is a normative juridical approach. Legal protection for children has been regulated in Law Number 17 of 2016. In the second amendment to the Child Protection Act, this action may be subject to Article 27 paragraph (3) of Law Number 11 Year concerning Information and Electronic Transactions. There needs to be learning to children how to respect and respect, law enforcement officials need to be improved for investigation and verification as well as human resources of law enforcement personnel themselves, as well as socialization for parents and students in schools about the impact and consequences of bullying.
\end{abstract}

Keywords: Cyber, Bullying, Social Media, Indonesia.

\section{Introduction}

Children are the next generation of the Indonesian people. Children have the right and obligation to participate in building the nation.Childrenare the subject and object of Indonesian national development in achieving the nation's aspirations, a just and prosperous society [1].

In recent times children tend to be victims of crime. One of them is Bullying. Bullying is the user of violence, threats, or coercion to abuse or intimidates others. This behavior can become a habit and involve an imbalance of social or physical power: intimidation, harassment, threats carried out both verbally and physically.

Bullyingcanis defined: the activity of repeated, aggressive behavior, physically or mentally. Bullying can be classified as individual behavior in a certain way to dominate others (gain power over another person). This can include verbal harassment or threats, physical violence or coercion and can be directed repeatedly against certain victims, perhaps by race, religion, gender, sexuality, or ability. Oppression habits can develop anywhere while there is an interaction between people, from starting at school, workplace, household, and other social environments[2].

In the modern era and globalization various cyber crimes such as fraud, online auctions, check forgery, credit/carding card fraud, identity fraud, child pornography,and others. One of the cybercrime that is experiencing development is cyberbullying. The National Conference of State Legislatures (NCSLs) explaining cyberbullying is a deliberate and repeated use of cell phones, computers, and other electronic communication devices to harass and threaten others. 
Adults and children who use technology and the internet as a means of communication are related that can lead to cybercrime called cyberbullying, where when communicating using social media, children can become victims of intimidation in the form of humiliation, defamation, extortion and other acts of intimidation sent via text, image or video messages. However,cyberbullying which will be discussed in this paper is where victims are under 18 years old [3]. However, if the victim is over 18 years old, the case will be categorized as cyberstalkingorcyber harassment.

Cyberbullying with child victims occurs in Indonesia and other countries, but for cyberbullying cases that lead to commitments to suicide still occur in several countries such as America, Britain, Canada, and several other European countries.It needs to be considered, because ifcyberbullyingis not overcome, then it is possible for countries that do not set policies and regulations to overcome cyberbullying will see children who are cheerful and full of the future become victims.

In Indonesia alone, there have been many cases of bullying against children in school. Both at the elementary, junior school and senior high school.From 2014 to August 2018, the Indonesian Child Protection Commission (KPAI) recorded 369 complaints related to the problem. That number is around $25 \%$ of the total complaints in education as many as 1,480 cases. Bullying referred to as KPAI as a form of violence in schools, defeating student fighting, educational discrimination, or complaints of illegal levies.

The case also reflects the moral degradation experienced by perpetrators cyberbullying. In essence, Humans have compassion towards one another. Humans are perfect creatures of God among other creatures because they have a reason, feeling, and will.. With the mind, compassion, the perpetrators of cyberbullying should not do things that can harm, harm and defame the reputation of others

Constitution of the Republic Indonesia Article 28B paragraph (2)mentioned "that every child has the right to survive, growth and development and has the right to protection from violence and discrimination. Protection of children based on the following principles: 1) Nondiscrimination; 2) The best interests for children; 3) The right to life, survive, and development; and 4) Acknowledgment of child's opinion.

This research will look at aspects of child protection in victims ofcyberbullying. Recently many bullying cases have happened. In order to see how the victim's child protection from cyberbullying, this study will discuss the legal protection of the child victims of bullying in social media.

\section{Research Methods}

The scope of this research is included in the study of law and is limited to the legal protection of children who are victims of cyberbullying which refers to the Criminal Code (KUHP), and Law Number 37 of 2016 Amendments to Both Law Number 23 of 2002 concerning Child Protection and Law Number 11 of the Year concerning Electronic Information and Transactions.

This study uses normative legal research methods. Normative or normative juridical law research is a method of legal research conducted by examining library material or secondary data [4]. In relation to normative research, the current research uses several approaches including: 1) Statute approach, statute approach is an approach made to various legal rules relating such as KUHP, Law of Children Protection and the Law on Electronic Information and Transactions and 2) Conceptual approach, conceptual approach, is used to understand the concepts of legal protection Conceptual approach, conceptual approach, is used to understand the concepts of legal protection children victims of cyberbullying. 


\section{Theory Approach}

\subsection{Legal Protection Theory}

Legal protection can mean that the protection provided by the law in order not tointerpret differently and is not harmed by law enforcement officials and can also mean the protection provided by law against something that also raises doubts. Legal protection can also raise questions that then cast doubt on the existence of the law. The law must provide protection to all parties by their legal status because everyone has the same position before the law.

Legal protection can be divided into two, classification: a) Preventive Legal Protection Protection provided by the government with the aim of preventing before the occurrence of violations. This is contained in laws and regulations with a view to preventing a violation and providing signs or limitations in carrying out an obligationand b) Repressive Legal Protection Repressive is the end of legal protection contain sanctions such as fines, imprisonment and additional penalties are given when a dispute has occurred,or an offense has been committed[5].

According to Satijipto Raharjo, legal protection is to protect human rights that are harmed by others, and that protection is given to the public to enjoy all the rights granted by law. Legal protection is an illustration of the functioning of the legal function to realize legal objectives, namely justice, usefulness, and legal certainty. Legal protection is a protection given to legal subjects by the rule of law, both written and unwritten in order to enforce the rule of law. In principle, everyone has the right to get protection from the law. Almost all legal relations must be protected by law. Therefore there are many types of legal protection[6]. As long as the regulation of victim protection has not revealed a clear pattern, in the positive criminal law that applies at this time more victims protection is "abstract protection" or "indirect protection". It means that various criminal defamation rules in the law so far have been in existence in essence protection of abstract directly to the legal interests and victims' rights. Indirect protection in the positive law regulation has not been able to provide maximum protection because reality in Indonesia shows that the applicable law certainly cannot guarantee certainty and sense of justice.

\subsection{Child Protection Theory}

Legal protection for children is an effort and activity of all levels of society in various positions and roles, who are well aware of the importance of children to the nation and nation in the future. If they have matured their physical and mental and social growth, then it is time to replace the previous generation. Child protection is a manifestation of justice in a society, so child protection endeavors in various fields of state life and society[7].

The issue of legal protection for children is one side of the approach to protecting children in Indonesia. As explained in Article 20 of the Child Protection Act which reads:"... States, governments, communities, families, and parents are obliged and responsible for the implementation of child protection ..."

Furthermore, in Article 59 of the Child Protection Act, it is stated that "... The Government and other state institutions are obliged and responsible to provide special protection to children in emergency situations, children who are dealing with the law, children from minority groups and isolated, exploited children economically and/or sexually, children who are trafficked, children who are victims of abuse of narcotics, alcohol, psychotropic substances, and other addictive substances (drugs), children victims of kidnapping, selling and trading, children victims of physical and/or mental violence, children those with disabilities, and children who are victims of mistreatment and neglect. 
DarwanPrinst said that in principle child protection must be able to guarantee the realization of the rights of children against a) religion; b) health; c) education; d) social; e) special protection. Child protection law must also be adapted to the development of international law and national law to date as well as the development of the reality on the ground in the application of child protection law to date [8]. It is certainly related to the issue of child protection is one side of the approach to protecting Indonesian children. In order for child protection to be carried out regularly, orderly and responsibly, it is necessary to have legal regulations that are in line with the development of Indonesian society which is fully imbued by Pancasila and Constitution[9].

\section{Discussion}

\subsection{Development of Cyber Bullying}

In s Marriem Webster Dictionary definedbully isto treat abusively or to affect using force or coercion. Bullying means is a negative act, which is aggressive or manipulative in a series of actions carried out by one or more people against another. Usually during a certain period of time-based on power imbalances. Bullying according to Coloroso is a conscious, deliberate, and cruel activity intended to hurt, instill fear through threats of further aggression, and create terror. Is this suppression planned first or suddenly, real or hidden, in front of you or behind your back, easily identifiable or hidden behind visible friendship, carried out by a child or group of children[10].

Victims of bullying are not just passive perpetrators of bullying situations. He also played a role in maintaining and preserving the situation of bullying by being silent. The victim generally does nothing and lets bullying take place on him because he does not have the power to defend himself or fight. The victim's silent attitude is certainly reasonable. The main reason, they think if reporting the bullying activities that happen to them will not solve the problem. Because if adults or law enforcers take action against bullying, the results will worsen the bullying situation of the victim.

In addition, children may have a value system that is complaining about others is a form of childishness, spoiled, weak and completely immature. For the victim, it is better to bear the burden of this suffering than to violate the values among children and complain of other children, the victims of bullying feel isolated and isolated by the group, friends, and social relations, but also cause them to feel unable and not interesting. People who have been intimidated often have difficulty forming good relationships, and tend to be difficult to live normally[11].

\subsection{Child Protection of victims of cyberbullying in the Criminal Code}

Protection of victims of bullying is not free from the consequences of the victim. Victims not only suffer physically but also suffer psychologically. The suffering suffered by victims as a result of bullying can be divided into:

1) 1) Physical impact: a) Criminal offenses relating to the deprivation of liberty are provided in Article333 KUHP; b) Crimes of persecution are regulated in Article351 KUHP; and c) Criminal extortion is regulated in Article 368 KUHP.

2) 2) Impact verbally and psychologically: a) Criminal threats are regulated in Article369 KUHP; b) Crime of unpleasant acts is regulated in Article335 KUHP; c) Crime of public threats is jointly regulated in Article336 KUHP.

\subsection{Child Protection of Cyber Bullying Victims in the Child Protection Act}


Legal protection for children who are victims needs to be dealt with quickly, including physical, psychological and social treatment, others based on the Child Protection Act. It can be seen in the following Article:

1) Article 59A Special protection for children as referred to inArticle 59 article (1) carried out through rapid handling efforts, including treatment and/or rehabilitation physically, psychologically, and socially, as well as prevention of diseases and other health disorders, psychosocial assistance during treatment to recovery, provision of social assistance for Children from disadvantaged Families, giving protection and assistance in every judicial process;

2) Article 69 has regulated in special protection for children victims of physical and psychological violence as referred to inArticle59 article (2) I containDissemination and dissemination of the provisions of laws and regulations that protect child victims of violence because of their lack of understanding of the law.It is important to monitor children in school and at home, Reporting, and Providing sanctions for victims of the final alternative legal path if the problem cannot be resolved because the child must be protected from the law.

\subsection{Child Protection Victims of Cyber Bullying in the Information and Electronic \\ Transaction Law}

Legal sanctions on bullying or oppression and humiliation can be punished by Law Number 11 Year concerning Information and Electronic Transactions, can be seen in the following article:

1) Article 27 article (3) Information and Electronic Transaction Law which reads: "Every person intentionally and without rights distributes and/or transmits and/or makes access to Electronic Information and/or Electronic Documents that have insult and / or defamation content;

2) The criminal threat for those who fulfill the inner elementarticle 27 ayat (3) is sentenced to a maximum of 6 years imprisonment and/or a maximum fine of Rp. $1.000 .000 .000,-$.

\subsection{Constitutional Court Decision Number 50/PUU-VI/2008 Strengthening the Protection of Children of Cyber Bullying Victims Constitutional}

'Court Decision Number 50/PUU-VI/2008 concerning constitutionality Article 27 paragraph (3) Information and Electronic Transaction Law confirms that Article 27 paragraph (3) of the Information and Electronic Transaction Law is a "delikaduan". Someone who feels his good name is defiled can attempt to complain to law enforcement officials. Regarding this, Article 108 paragraph (1) and paragraph (6) of Law Number 8 of 1981 concerning Criminal Procedure Law, which states that every person who experiences, sees, witnesses and or becomes a victim of an event that constitutes a criminal act has the right to file a report or complaints to investigators and or investigators both oral and written.

\subsection{Future Prospect Protection of Cyber Bullying Victim Child in the Penal CodeI}

Relation to the cyber bullying action in the draft of Penal Code does not address the issue of cyber bullying in its provisions, because of the concept of the Penal Code in chapter 8 of the Second Book, the fifth paragraph, in the first paragraph up to the second paragraph, regulates actions that cause damage to the electronic system used by the government in the defense, while the third chapter discusses child pornography through computers. So the setting 
up of cyber bullying can still be seen in the articles of insult, mild humiliation, fitnah, morals and threats inside draft of Penal Code.

On this matter, there needs to be a special legal socialization regarding the regulation of direct suppression or bullying on social media, namely cyberbullying giving criminal sanctions both to law enforcers themselves and to the public in order to better understand sanctions against perpetrators [12]. So it is necessary to have separate law rules regarding the rules of bullying directly or in social media namely cyberbullying and legal sanction. Judging from the lack of legal protection for victims of cyberbullying in Indonesia, Article 27 paragraph 3 of the Information and Electronic Transaction Act can still be used as a reference for those who feel victims of cyberbullying, it is expected that the public can complain of bullying behavior committed against Article 27 paragraph 3 of Law Information and Electronic Transactions, not Articles 310 and 311 of the Criminal Code.

\section{Conclusion}

The case of cyberbullying against children is contrary to Article 27 paragraph (3) and (4), Article 28 paragraph (2) of Law Number 11 of 2008 concerning Information and Electronic Transactions. Also contrary to the Criminal Code, namely Article 368 paragraph (1) concerning Extortion and threats and Article 310 of the Criminal Code concerning Humiliation. Defamation in Social Media, in the Criminal Code,has clearly regulated that humiliation is a complaint of complaint. Constitutional Court Decision Number 50/PUU$\mathrm{VI} / 2008$ concerning the constitutionality of Article 27 paragraph (3) of the ITE Law confirms that Article 27 paragraph (3) of the ITE Law is a "delikaduan". Someone who feels his good name is defiled can attempt to complain to law enforcement officials. Related to this, Article 108 paragraph (1) and paragraph (6) of Law Number 8 the Year 1981 concerning the Criminal Procedure Code. In addition, the protection of child victims of cyberbullying is also regulated in Article 59A and Article 69 of the Child Protection Act. There needs to be an awareness from the community not to make oppression or bullying a culture that is considered to have no adverse effects on children. 


\section{References}

[1] Arliman S, L, "Peran Pemerintah Daerah Dalam Perlindungan Hak Anak Berdasarkan Undang-Undang Nomor 35 Tahun 2014 Tentang Perlindungan Anak", Journal Yustisia, 2rd,Vol. 22, 2015, pp. 80-92.

[2] Frensh, W, Kalo, S, Mulyadi, M, Bariah, C. "Kebijakan Kriminal Penanggulangan Cyber Bullying Terhadap Anak Sebagai Korban” USU Law Journal, 2rd, Vol. 5, 2017, pp. 34-45.

[3] Pandie1, MM, Weismann, I, T, J, "Pengaruh Cyberbullying Di Media Sosial Terhadap Perilaku Reaktif Sebagai Pelaku Maupun Sebagai Korban Cyberbullying Pada Siswa Kristen Smp Nasional Makassar”, Journal Jaffray, 1st, Vol. 14, 2016, pp. 41-62.

[4] Arliman, S, L, "Peranan Metodologi Penelitian Hukum di Dalam Perkembangan Ilmu Hukum di Indonesia”, Soumatera Law Review, 1st, Vol. 1, 2018, pp. 112-132.

[5] Arliman, S, L, "Perlindungan Anak Oleh Masyarakat Ditinjau Dari Mazhab Sejarah Di Dalam Penerapan Prinsip The Best Interest Of The Child Pada Kehidupan Anak Di Indonesia" Journal Era Hukum, 2nd, Vol. 1, 2017, pp. 123-149.

[6] Raharjo, S, "Ilmu Hukum", PT. Citra Aditya Bakti: Bandung, 2000.

[7] Prinst, D, "Hukum Anak Indonesia", Citra Aditya Bakti: Bandung, 2003.

[8] Abdussalam, R, Desasfuryanto, A, "Hukum Perlindungan Anak", PTIK: Jakarta, 2016.

[9] Soetedjo, W, Melani, "Hukum Pidana Anak", Refika Aditama: Bandung, 2011.

[10] Coloroso, B “Stop Bullying”, Serambi Ilmu Pustaka: Jakarta, 2007.

[11] Sopiani, M, “Analisis Perlindungan Hukum Terhadap Anak Sebagai Korban Bullying Di Media Social”, Universitas Lampung: Lampung, 2018.

[12] Student Reports Of Bullying, "Results From The 2001 School Crime Supplement To The National Crime Victimization Survey", US Nastional Center Fo Education Statistics \& Cambridgeshire.Gov.Uk: U.S Dept. Of Justice, Fact Sheet, 2001.

[13] Hariyadi, S. "dampak negatif bermain game dan menonton tayangan bermuatan kekerasan pada anak (penyuluhan pada siswa sdn 06 pasar muara labuh, kab. Solok selatan)." Menara Ilmu 10.73 (2016). 